\title{
Synopsis of the Accounting Research in Hellas
}

\author{
Yiannis K. Yiannoulis ${ }^{1,2}$ \\ ${ }^{1}$ Lecturer of Accounting and Auditing, School of Economics and Management Sciences, Department of Accounting \\ and Finance, Hellenic Mediterranean University, Greece \\ ${ }^{2} \mathrm{PhD}$ Candidate, School of Business and Law, Frederick University, Cyprus \\ Correspondence: Lecturer of Accounting and Auditing, School of Economics and Management Sciences, \\ Department of Accounting and Finance, Hellenic Mediterranean University, Greece. \\ https://orcid.org/0000-0002-8686-5747
}

Received: February 10, 2021

Accepted: February 25, 2021

Online Published: February 26, 2021

doi:10.5430/afr.v10n1p75

URL: https://doi.org/10.5430/afr.v10n1p75

\begin{abstract}
The scope of this paper is to provide a synopsis of the accounting research in the Hellenic corporate environment. In addition, we will examine the quality of audit in publicly listed companies, as prescribed by the term "audit gap"; this term specifies and characterizes the growing public concern regarding the audit report credibility and efficiency.

These two topics (Hellenic accounting and auditing environment) have been isolated and examined from the previous researchers in depth; however, the novel think of this study is that it examines this "audit gap", which is the gap between the expectations the public has from the auditors and what auditors actually do in their reports (Caramanis, 2008).

This research is useful for capital market and audit authorities as they should focus more on improving audit work and preparing accounting and auditing standards that prevent earnings management. However, our study has the limitation that it examined the capital market, audit and accounting environment of a single country, i.e. Hellas/Greece.
\end{abstract}

Keywords: accounting, auditing, corporate governance, earnings management, Hellas

\section{Introduction}

The scope of this paper is to provide a synopsis of the accounting research in the Hellenic corporate environment.

Why Hellas? Hellas is a "natural experiment" in the sense that it has special characteristics that substantially differ from other European countries. Hellas is a small continental Europe country; however, it has many socio-political features that distinguish the specific country from other European countries.

As Lazarides (2007, p. 2) states "Greece has the same characteristics as Spain, Portugal and other countries that are ranked in the Continental Europe corporate governance system (Franks et al., 2008; Kaufmann et al., 2009; Shleifer and Vishny, 1997)".

Hellas presented one of the lowest ownership dispersion percentages among civil law countries, with $67 \%$ ownership concentration (La Porta et al., 1999, Note 1); in addition, Hellenic Capital Market Commission (www.hcmc.gr) showed that ownership dispersion in Athens Stock Exchange (ASE), in 2001, was middle to low (i.e. about 35\% based on shareholders who own less than $1 \%$ of the stock and around $50 \%$ on shareholders who hold less than $5 \%$ of company's shares).

In listed companies, the decision making and administration processes are mainly controlled by big (mainly family) shareholders; small and medium-sized enterprises are basically those that present a family character, while the larger, in market capitalization, firms tend to have higher dispersion (Note 2).

However, family firms have some competitive advantages; for example, as Spanos et al., (2004, p. 3) state "altruistic behavior and trust can also produce many advantages in the family firm's context e.g. collective ownership by all family members working in the firm, reduction of information asymmetries among family members and commitment of corporate leaders to the firm's long term performance" (Note 3). 
In addition, Hellenic corporate governance system mainly follows the insider/bank-based system; specifically, it shows: a) few independent committees, b) limited financial disclosure (mainly for tax purposes) and c) weaker investor protection.

Regarding earnings management, Leuz et al. (2003) and Bhattacharya et al. (2003) found that Hellenic companies manipulate their accounting numbers more compared to other European countries.

Last fifteen years (starting around 2005) Hellas faced three major financial events that affected capital market as well as Hellenic corporate environment; those events include the: a) Olympic Games in 2004 and the implementation of International Financial Reporting Standards (IFRS) on listed companies (applied on the financial statements starting from $1^{\text {st }}$ January 2005), b) global financial crisis (started in US around 2007) and c) Hellenic debt crisis (started in 2009-2010).

In this paper, we will also examine the quality of audit in publicly listed companies, as prescribed by the term "audit gap"; this term specifies and characterizes the growing public concern regarding the auditor report credibility and efficiency. These two topics (Hellenic accounting and auditing environment) have been isolated and examined from the previous researchers in depth; however, the novel think of this study is that it examines this "audit gap", which is the gap between the expectations that public has from the auditors and what auditors actually do in their reports (Caramanis, 2008). This term is examined in addition to earnings management phenomenon, which raises the public concerns about the quality of financial information provided in financial statements prepared by companies' management and audited by qualified/certified auditors.

The topics investigated are crucial and extremely important as they affect capital providers' decisions to invest; in addition, this study will help regulators in order to recognize and prevent bad economic behavior that will damage "public trust"/confidence of financial statements.

In our opinion, these topics have been under-researched and we will try to fill that gap with this research. Hellenic cultural, political and economic environment are being influenced by Eastern and Western influences (Caramanis, 2005).

The development of accounting, auditing and corporate environment in Hellas can be linked to: a) cultural factors, b) family structure of business (Note 4), c) law, d) political and e) institutional factors (Ballas, 1994).

In addition, "Hellas is considered to be a low trust society with strong preference for state regulation (Ballas et al., 1998 and 2012).

The paper is organized as follows: in the second section we discuss about the Hellenic capital market from 1996 till now and in the next section we look into the audit framework the last half century (from 1955). In the fourth section we examine the Hellenic accounting standards evolution and in the fifth section we conclude.

\section{Hellenic Capital Market Environment - Athens Stock Exchange - www.athex.gr}

In Hellas listed companies are mainly family firms and ownership dispersion is low in most of the small and medium sized companies; large families are involved in management and competition for control at the company level is low (Note 5).

Large shareholders may act as an effective monitoring mechanism of management and, thereby, could improve company's financial performance; however, as in Type II agency problems, controlling blockholders can use their voting power in order to extract private benefits at the expense of minority shareholders (Note 6).

In that case, the question is how to align the interests of strong block-holders and weak minority shareholders (Spanos, 2005, p. 16); the cost of the involvement with management and control for minor shareholders is higher than the cost of exit and for that reason they choose to sell stock (use their "exit option") if they do not agree with management choices.

However, the lack of market for corporate control (advanced and liquid capital market) poses problems regarding the effectiveness of minority shareholders' exit option.

As owners are involved in management and finance is mainly provided by banks (and not by capital markets), there is lower need for financial information in order to take important investment and financial decisions.

The number of Hellenic is diminishing every year after 2000; specifically, from 350 listed companies in 2000 to around 170 in the end of 2020 (Note 7). The main reason for this reduction is delisting, which includes voluntary and involuntary. 
Hellenic capital market (ASE - www.athex.gr) experienced a "cycle of self-fulfilling expectations" at the end of 1999; the "massive" entrance of individual investors, without: a) any previous investment experience and b) knowledge of capital market risk, resulted in huge increases in stock prices (ASE capitalization recorded an annual increase in 1999 around $200 \%$ !!). After that "bubble burst" there was an extensive stocks' liquidation that lead to big reduction in the following years.

A study of Balios et al. (2015, p. 69) examined for the companies that were listed in ASE on $1^{\text {st }}$ January of 2005 , what was their status (remaining listed, delisted voluntary or involuntary) on the end of 2012. Their sample was around 240 companies, of which: a) 11 were involuntary delisted and b) 42 were delisted by the stock market authorities (involuntary delisting). The authors found that "companies with poor liquidity, high leverage, big stock price decline and lack of interest from investors for the company (low trading activity) have higher probability to be delisted".

According to our research the main reason for this massive delisting is poor corporate governance attributed to Hellenic listed in ASE firms, as well as the fact that in the period between 1996 and 2004 (and especially in 1999 and 2000) many companies entered to the stock market but they did not fulfill investors' expectations.

Regarding IPOs' performance Papaioannou and Travlos (1995) examined the IPOs in ASE during the period 1987 to 1993; they found on average, initial returns more than 30\%. During most of this period, according to ASE regulations, there was an offer price guarantee for a six months' period after the initial price offering (this changed in 1990). Regarding the daily price limit, this was +/- 8\% from 1992 till 1996, while in 1997 the limit became +/- 99\% for the first three days of trading and then $+/-8 \%$.

Tsangarakis (2004, p. 27) highlights the main differences in the IPO process between ASE and the main international capital markets; specifically, one of the most important differences is that ASE does not have a developed secondary offerings market. In addition, the pricing of the IPO, unlike US practice, is executed a month before the offerings period and for that reason pricing/waiting risk is greater in ASE. Lastly, regarding the allocation of shares this is not controlled by the underwriter; specifically, investors subscribe to the IPO and according to the total demand the allocation of shares is executed. The IPO stock starts trading about one month after the sale of the IPO shares to the public; for that reason, investment uncertainty is high, which affects negatively: a) flotation costs and b) IPO share price.

Recent research studies regarding the quality of Corporate Governance in ASE listed firms have shown medium to low compliance to International Corporate Governance Codes (i.e. Spanos, 2005 and Florou and Galarniotis, 2007). In addition, as Spanos (2005) postulates "Corporate governance failures have been identified as one of the key reasons of the Greek capital market's underperformance during the last three years (2001-2004".

Alexakis et al. (2006) attempted to relate the mean returns and price volatility of a selected sample of 30 firms (Note 8) listed on ASE to the implementation of CG laws; regarding the periods selected they split their period from September 1999 to February 2004 to three sub-periods based on the time specific CG laws became effective. Their results showed that volatility (measured by the standard deviation) during the sample periods differs substantially; specifically, in the mid-CG period (from 7 May 2001 to 26 June 2002) has decreased. According to the authors this finding showed that the Hellenic capital market took the introduction of CG laws very seriously.

But what about Hellenic capital market efficiency? A study by Dicle and Levendis (2011, p. 245, Conclusion) showed that "a small percentage of the Greek market may be blamed for market level results that may question market efficiency. These are usually smaller and less liquid stocks".

According to Tsipouridou and Spathis (2014, p. 39) "The significant expansion of the Athens Stock Exchange (ASE) in late 1990s turned many firms from private-family owned businesses to publicly listed entities (Spanos, 2005) without changing the existing relatively high levels of family ownership" (Lazarides, 2010).

Spanos et al. (2008) examined (using questionnaire) a sample of 120 listed in ASE companies from which 98 where family firms and the rest non-family; they found that most of family firms lack proper corporate governance and especially in: a) risk management, b) Board of Directors' independence, c) Board committees (i.e. compensation and audit committees) and d) directors' remuneration information.

\section{Hellenic Audit Framework and Corporate Governance Quality}

Regarding the interrelationships between ownership structure and board characteristics of Hellenic listed firms in ASE, Bekiris (2013), for a sample of firms for the period from 2000 to 2006, found that in companies where the

Chief Executive Officer (CEO) is also Board chairman (thus weakening corporate governance quality) the 
independent directors and blockholders ownership tend to be lower. More interestingly, there is a negative relationship between managerial ownership and board size (this is NOT in line with agency theory, but is in line with Lasfer (2003), and suggests that managers will generate profits by adopting a larger board.

In order to restore investors' confidence in ASE, new laws were introduced and voluntary corporate governance codes were implemented.

Studies regarding the quality of corporate governance (i.e. Makridakis et al., 1997; Tsipouri and Xanthakis, 2004; Spanos, 2005; Florou and Galarniotis, 2007 and Spanos et al. 2008) showed that: a) family firms had lower corporate governance score compared to non-family firms, b) shareholders' rights appear to be well protected for both family and non-family firms, c) the principle "one-vote one-share" is compulsory by law, d) family firms have lower quality of accounting systems and e) in the majority of family firms the Chairman of the Board is serving also and as company's Chief Executive Officer (CEO).

According to Mertzanis (2001) "the two tier boards is considered to be a non-existent element in the Greek corporate structure".

The legal system of Hellas is based on the French civil-law tradition; Hellenic companies are governed by Law 2190/1920; the governing body is General Meeting of shareholders which elects the Board of Directors (BoD) and most Hellenic firms are ruled by unitary BoD.

According to Ballas (1994, p. 116) "Up to 1955 there was no systematic attempt to force an external audit of financial statements of big private companies; this made oppression of minority shareholders very easy".

Dedoulis and Caramanis (2007) reached to the same conclusions.

Law 3329/1955 introduced the Society of Sworn Accountants (SOL in Greek); "SOL operated in a cartel-like fashion...The numbers of auditors was fixed Members of SOL enjoyed a very peculiar status. Though SOL was a public sector body and their assistants were not civil servants but "civil functionaries. Thus, they enjoyed an exceptional degree of professional independence. Furthermore, auditors' fees were non-negotiable and they did not have to go out to search for clients" (Ballas, 1994, p. 116-7).

However, in 1991 with Law 1969/1991, it was accepted that the compulsory audit of firms should be conducted by members (individual auditors) of a new bod called Sworn Accountants - Auditors (SOEL in Greek). The private/public companies were free to choose their auditor and the audit fee was not fixed any more.

Auditing profession was liberalized in 1992; most of SOL members introduced SOL S.A. a new audit firm, which dominated the audit market, despite Big-4 and other international and national firms.

Audit profession has often been criticized regarding their reporting credibility (Leventis et al., 2011).

But what the effect of Arthur Andersen's (AA) collapse in September 2002 in the audit services market shares of Big-4 audit companies in Hellas? A research by Ballas and Fafaliou (2008) examined the European Union audit market, (of the EU-15 countries) for the period 1998 to 2004; for the overall sample they found that "concentration" in the aggregate sample increased over time. Regarding Hellas, the market share of SOL S.A. reduced after 2002, which means that the market share of AA was taken by the Big-4 international accounting firms and by the local audit company (SOL S.A.).

A study of Dimitras and Iatridis (2013, p. 158) showed that "firms that are audited by a Big-4 auditor do not necessarily report higher value relevance in the reported financial numbers when confronted with a crisis". For that reason, we argue that is very important to increase the credibility of audited financial statements especially during this period.

Ballas et al. (2012, p. 53) concluded "finally despite the reforms of the audit profession in the early 1990s, the quality of audits in Greece is debatable while quality control, legislated in 2004, was never implemented".

Regarding auditing standards, Hellas is fully harmonized with the International Standards of Auditing (ISA) and the European Union Directives (Tsipouridou and Spathis, 2014, p. 40, Auditing Standards).

Regarding auditors report a study by Grant Thornton (2010) showed that the most frequent qualification for the fiscal year 2009 for ASE listed firms is the "uncertain outcome of future State tax audits". However, there is a "particularity of the Greek auditor's report" in the sense "that there is not a clear distinction between unqualified and qualified opinion. For instance, a qualified opinion can include, in the explanatory paragraph, remarks about matters that both "affect" and do not affect the auditor's overall opinion. However, it could end with the phrase such as "with the exception of the consequences of the above issues, in our opinion, the aforementioned financial 
statements give a true and fair view of the financial position of the firm as of 31 December 20XX". Thus, it is in the subjective judgement of the user to decide whether or not the remarks are materially important, and whether or not they should be taken into consideration" (Tsipouridou and Spathis, 2012, p. 66, Auditor's report).

International research (mainly based in US sample) finds contradicting results regarding the (potential) relationship between earnings management and the likelihood of receiving a qualified opinion. For example, Bradshaw et al. (2012) find no relationship, while Bartov et al (2001) find a positive link between the absolute value of discretionary accruals and the possibility to receive a qualified opinion.

In the Hellenic setting, Tsipouridou and Spathis (2014) divided the qualified opinions in two categories: a) qualified for "going concern" and b) qualified for other reasons. In addition, they tested that relationship to "financially distressed" companies.

Although there were many improvements in the field of Corporate Governance in the last two decades, empirical studies have shown that these are mainly apparent in a limited number of large capitalization listed on ASE firms (Spanos et al., 2008; Chalevas and Tzovas, 2010 and Dimitropoulos and Asteriou, 2010).

Regarding Corporate Governance (CG) (Note 9) as Spanos et al. (2008) state "Although improvements in CG occurred in Greece, they are mainly confined to a small number of listed companies that are more in tune with the international corporate stage", (Tsipouri and Xanthakis, 2004 and Spanos 2005).

Another study by Dimitropoulos and Asteriou (2010) reaches the same conclusion.

Hellas introduced the "comply or explain" principle with Law 3873/2010 (Note 10); this law obliged "listed companies to disclose an annual Corporate Governance Statement (CGS) in their annual report" (Neratzidis and Tsamis, 2017, p. 366).

\section{Hellenic Accounting Standards and the Effect of IFRS Adoption}

Hellas accounting setting is mainly tax-based and conservative (Ballas, 1994 and Spathis and Georgakopoulou, 2007); financial statements are not the main source of information; banks are the main capital providers and "they often develop personal relationships with firms (Tzovas, 2006). In the relationship-based system, banks may arrive at their credit decisions based on information obtained directly from the owners of the firms, thereby undermining the importance of public accounting information (Tzovas, 2006)" (Tsipouridou and Spathis, 2014, p. 39).

The Hellenic General Accounting Principles (HGAP), with law 1882/1990, were compulsory for all companies audited by SOEL members (qualified auditors). However, the influence of tax laws in the companies' accounting environment is significant: "most firms continued using tax law regulations even when reporting to their shareholders. The reason was that failure to comply with tax regulations could result in significant penalties, whereas failure to comply with the requirements of the Accounting Plan had practically no effect" (Ballas, 1994, p.113).

A study by Ballas et al. (2012) examined the accounting treatment regarding unrealized results (gains or losses) and the capital market reaction to "mark to market" accounting policy choice of equity investments of Hellenic listed firms during the period 2002 till 2004 (before the adoption of IFRS). In order to reduce losses from the decline of the market value of shares in that period in ASE, most firms choose to adopt different accounting policy for gains and for losses. Specifically, listed firms chose to take valuation gains to the income statement and losses through equity; however, this treatment of capital losses affected negatively the stock market price.

According to the authors the above market reaction means that the ASE is an efficient market and "investors in the Athens Stock Exchange react negatively to the valuation adjustment that has no cash flow implications and they react negatively to opaqueness in the financial statements, at least with regard to share valuation adjustment" (Ballas et al., 2012, p. 60, Conclusion).

In 2005 the compulsory adoption of IFRS was compulsory to companies listed in ASE (Spathis and Georgakopoulou, 2007).

The first study that analyzed and examined the effect of IFRS adoption in financial statements of listed companies was a study from Grant Thornton (an international audit company) in 2006; specifically, the study examined the published financial statements of 2004 and 2005. The results showed that IFRS adoption had: i) an overall positive impact of around 5\% in equity (Note 11), ii) positive impact in firms' annual results through the increase of the useful lives of depreciable fixed assets and iii) a negative impact on financial results through the recognition of deferred tax liabilities and the creation of provision contingent income tax liability. 
It is evident that the compulsory transition of financial statements from the Hellenic Generally Agreed Accounting Practices (HGAAP) to International Financial Reporting Standards (IFRS) increased their reliability, transparency and comparability (Ballas et al., 2010).

However, the study of Karampinis and Hevas (2011) showed that the value relevance of Hellenic financial statements has slightly only improved; specifically, they compared earnings' value relevance and conditional conservatism between: i) the last three years of the application of Hellenic accounting and ii) the first three years of IFRS implementation in ASE listed companies. They found insufficient evidence of improvements in these accounting properties after the mandatory adoption of IFRS.

On the contrary, Iatridis and Rouvolis (2010) found that the book value of equity and net profits of companies listed on ASE were more value relevant in the first two years of mandatory adoption of IFRS than in 2004, the last year of application oh HGAAP.

Tsalavoutas and Dionysiou (2013) found that (using financial statement of listed in ASE firms for the year 2005) listed companies applied the relevant requirements of IFRS regarding Goodwill (IFRS 3 and 36) in 70\% and around $50 \%$ respectively.

Ballas and Tzovas (2010) found similar results.

In another study Baboukardos and Rimmel (2014) examined specifically the relevance of goodwill disclosures under IFRS for the fiscal year 2008; their dependent variable was the market value of equity four months after the companies" fiscal year end. They found that purchased goodwill disclosures as well as "fair value" accounting (FVA) under IFRS were value relevant. A possible explanation of this is that ASE is NOT "fully efficient" and that "the application of FVA may enhance the decision usefulness of financial reporting" (Baboukardos and Rimmel, 2014, p. 12 , last paragraph).

During the crisis period Iatridis and Dimitras (2013) compared the value relevance of listed firms' financial statements that are being audited by Big-4 companies in five European countries (i.e. Portugal, Ireland, Italy, Spain and Hellas) for the period from 2005 to 2011. They found that Hellenic companies showed: i) negative discretionary accruals, ii) higher possibility to engage in earnings management, if the company is audited by a Big-4 audit company, iii) negative relationship between size and earnings management, iv) positive relationship between growth and earnings management and v) "show lower quality financial numbers during the crisis perhaps in an effort to somewhat influence investors' perceptions and to avoid getting too exposed" (Tsipouridou and Spathis, 2013, p. 158, 5.3. Value relevance)

\section{Conclusion}

A study by Bae et al. (2008) showed that Hellas, among the European Union 15 countries, had the second largest difference between its national accounting system and IFRS. For that reason, the change of corporate accounting system was very difficult for accountants.

As Baboukardos and Rimmel (2014) state "In addition, because Greece is a low-trust society (Note 12), its accounting environment is highly formalistic...Another important sequence of the highly formalistic environment in Greece is the absence of extensive supplementary disclosure requirements", (Baboukardos and Rimmel, 2014, p. 2).

Hellas industrialized after World War II and although in the first years had a very rapid growth after it faced structural economic problems and stagnation; this was the case until 2001, when Hellas entered in the European Monetary Union (EMU).

After that Hellas had a stable macroeconomic environment with low currency risk; in addition, Athens Stock Exchange (ASE - www.athex.gr) for the period 1996 till the beginning of 2000 showed the highest growth of any other capital market in the developed world. The number of listed companies increased substantially, and ASE was upgraded to a mature capital market in 2001.

Regarding ownership structure Hellas ranks in the middle of around 50 countries, when ownership is being measured by adding the percentage share of the three largest shareholders in the ten non-financial listed companies (La Porta et al., 1998).

Hellas is a code-law, continental European country with "a stakeholder-oriented and taxation driven national accounting system (Ballas et al., 1998 and Nobes 2008 and 2011)" (Baboukardos and Rimmel, 2014, last paragraph).

Asimakopoulos et al. (2008/2009) examined the determinants of profitability (Note 13) for a sample of Hellenic non-financial firms listed in ASE for the period from 1995 to 2003 (before the adoption of IFRS and before the 2010 
debt crisis); they found that firm profitability was positively related with: a) size, b) sales growth and c) investment amounts. In contrast, profitability was negatively affected by: a) leverage and b) current assets.

In addition, contrary to the belief, the adoption of Euro, in 2002, had a negative effect on firms' profitability.

Regarding the determinants of firm survival in ASE, the same study (i.e. Asimakopoulos et al., 2008/2009) applied similar with previous studies (i.e. Hensler et al., 1997 and Macey et al., 2008) survival models. They examined the following firm-specific determinants of firm survival: a) leverage, b) size, c) corporate governance (i.e. Board of Directors composition, ownership dispersion and market for corporate control), d) firm age and "market timing"/"window of opportunity hypothesis" and e) the sectoral impact and the effect of macroeconomic environment. Their data were the Initial Public Offerings (IPO) for the period 1993 to 2002 and traced these companies if they were delisted on the end of 2006. The interesting findings were the following: i) leverage is negatively associated with firm survival (in accordance with Fotopoulos and Louri, 2000) and ii) large firms have lower possibility not to survive (negative relationship with size, Note 14). Regarding corporate governance quality their results showed that "agency theory alone cannot explain the factors affecting the survival of firms on the Athex" (Asimakopoulos et al., 2008, p.20).

Focusing on Corporate Governance enforcement, a study by Tsipouri and Xanthakis (2004), using questionnaire, showed that "there is a weaker compliance on average concerning the role of stockholders and corporate social responsibility, the organization of $C G$, the effective role of the independent members of the board (which could be attributed to companies with family control and the small pool of potential independent board members), disclosure of remuneration and risk management" (Tsipouri and Xanthakis, 2004, p. 25) (Note 15).

The main characteristics of the Hellenic corporate environment are:
1. "High concentration of ownership
2. Weak investor protection and enforcement
3. Insider governance
4. Limited capital market
5. Not active external control mechanisms (i.e. market for corporate control and labor market)
6. No clear distinction between management and ownership
7. One-tier boardroom and
8. Not active involvement of institutional investors in management or controlling"

(Neratzidis and Tsamis, 2017, p. 367).

To conclude, according to our opinion, the main finding of this study is that Hellenic listed companies engage in more earnings management than other European countries; in addition, this is not diminishing when the company is audited by a Big-4 audit company.

In addition, the amount of financial scandals in Hellenic corporate environment and the huge amount of involuntary delistings from ASE (TABLE-SPECIFY): a) question the credibility of audit profession, ii) increase public worries regarding the quality of audit work and iii) regarding actual independence of auditors from company's management.

As Tsipouridou and Spathis (2012, p. 66, 2.4. The audit market) state "Unfortunately, ELTE (Note 16) has received considerable criticism because it has not yet become an effective enforcement. In the Greek environment of weak disciplinary authorities and low probability of litigation by third parties, concerns over auditors' potential opportunistic behavior still remain".

The authors documented that because of: i) Hellas specific characteristics in the economic and corporate environment (many small- and medium- sized companies and limited number of small firms), ii) institutional setting (family ownership, not developed capital markets and weak market for corporate control), iii) code-law country, iv) the relatively small audit market (not enough firms compared to the great amount of individual auditors and audit companies) and v) weak enforcement of audit laws and the weak control on auditors' work by ELTE, auditors "have weak incentives to prevent earnings management (Tsipouridou and Spathis, 2012, p. 76, Conclusions, limitations and future research).

This research is useful for capital market and audit authorities as they should focus more on improving audit work and preparing accounting and auditing standards that prevent earnings management (the adoption of IFRS improved 
the quality of financial statements). In addition, it would be beneficial by potential investors, who base their investment decision to reported financial statements which are biased by earnings management.

However, our study has the limitation that it examined the capital market, audit and accounting environment of a single country, i.e. Hellas. Future research can compare the Hellenic environment with that of another continental European country (i.e. Italy, Spain and Portugal) with the same characteristics.

In addition, another stream of research could examine how Hellenic capital market (ASE - www.athex.gr) react to companies' earnings management procedures.

\section{References}

Balios, D., Eriotis, B., Missiakoulis, S., \& Vasiliou, D., (2015). Delisted versus voluntary delisted versus remain listed: an ordered analysis". Applied Economic Letters, 22:1, 66-70. https://doi.org/10.1080/13504851.2014.927559

Ballas, A. A., Chalevas, C., \& Tzovas, C., (2012). Market reaction to valuation adjustments for financial instruments: Evidence from Greece", Journal of International Accounting, Auditing and Taxation, 21, 52-61. https://doi.org/10.1016/j.intaccaudtax.2012.01.004

Ballas, A. A., Hevas, D., \& Neil, D. (1998). The state of the accounting and the state of the state. Journal of Management and Governance, 2, 267-85. https://doi.org/10.1023/A:1009935527195

Ballas, A. A. (1994). Accounting in Greece. European Accounting Review, 3(1), 107-21. https://doi.org/10.1080/09638189400000005

Berghe, L. A. A., \& Carhon, S. (2003). Agency relations within family business system: an explanatory approach. Corporate Governance: An International Review, 11(3), 171-9. https://doi.org/10.1111/1467-8683.00316

Bhattacharya, U., Daouk, H., \& Welker, M. (2003). The world price of earnings opacity. The Accounting Review, 78(3), 641-78. https://doi.org/10.2308/accr.2003.78.3.641

Caramanis, C. V. (2008). Current Audit: Theory and practice according to International Auditing Standards. AUEB Editions, Athens (in Greek).

Caramanis, C. V. (2005). Rationalization, charisma and accounting professionalization: Perspectives on the intra-profession conflict in Greece, 1993-2001". Accounting Organizations and Society, 30(3), 195-221. https://doi.org/10.1016/j.aos.2004.01.002

De Paola, M., \& Scoppa, V. (2001). The role of family ties in labor market: an interpretation based on efficiency wage theory". Review of Labor Economics, 15, 603-24. https://doi.org/10.1111/1467-9914.00179

Dimitropoulos, P. E., \& Asteriou, D., (2010). The effect of board composition on the informativeness and quality of annual earnings: Empirical evidence from Greece. Research in International Business and Finance, 24:2, 190-205. https://doi.org/10.1016/j.ribaf.2009.12.001

Fama, E., \& Jensen, M. (1983). Separation of ownership and control. Journal of Law and Economics, 26, 301-25. https://doi.org/10.1086/467037

Florou, A., \& Galarniotis, A. (2007). Benchmarking Greek corporate governance against different standards. $\begin{array}{llll}\text { Corporate } \quad \text { Governance: An International } & \text { Review, } & \text { 15(5), }\end{array}$ https://doi.org/10.1111/j.1467-8683.2007.00614.x

Jensen, M. C., \& Meckling, W. H. (1976). Theory of the firm: managerial behavior, agency costs and ownership structure. Journal of Financial Economics, 3, 305-60. https://doi.org/10.1016/0304-405X(76)90026-X

Koutoupis, A. G. (2012). Importing international corporate governance codes in Greek publicly listed enterprises: a case study analysis. International Journal of Organizational Analysis, 20(4), 447-63. https://doi.org/10.1108/19348831211268634

La Porta, R., Lopez-de-Silanes, F., \& Shleifer, A. (1999). Corporate ownership around the world. Journal of Finance, 54, 471-517. https://doi.org/10.1111/0022-1082.00115

Leuz, C., Nanda, D., \& Wysocki, P. (2003). Earnings management and investor protection: An international comparison. Journal of Financial Economics, 69(3), 505-27. https://doi.org/10.1016/S0304-405X(03)00121-1 
Neratzidis, M. (2015). Measuring the quality of "comply and explain" approach: Evidence from the implementation of the Greek corporate governance code. Managerial Auditing Journal, 30(4-5), 373-412. https://doi.org/10.1108/MAJ-08-2014-1060

Neratzidis, M., \& Filos, J., (2014). Recent corporate governance developments in Greece. Corporate Governance: The International Journal of Business in Society, 14(3), 281-99. https://doi.org/10.1108/CG-10-2011-0080

Neratzidis, M., Filos, J., Tsamis, A., \& Agoraki, M. E. (2015). The impact of the Combined Code in the Greek soft law: evidence from "comply or explain" disclosures. International Journal of Law and Management, 57(5), 445-60. https://doi.org/10.1108/IJLMA-05-2014-0036

Neratzidis, M., \& Tsamis, A., (2017). Going back to go forward: on studying the determinants of corporate governance disclosure. Corporate Governance: The International Journal of Business in Society, 17(3), 365-402. https://doi.org/10.1108/CG-07-2016-0145

Papaioannou, G. J., \& Travlos, N. G. (1995). The Initial Public Offers in Greece. In The Greek Financial System: Trends and Prospects, Chapter 9, Edited by G. Provopoulos, 214-62.

Shleifer, A., \& Vishny, R. W., (1997). A survey of Corporate Governance. Journal of Finance, 52, 737-83. https://doi.org/10.1111/j.1540-6261.1997.tb04820.x

Spanos, L. (2005). Corporate governance in Greece: development and policy implications. Corporate Governance: The International Journal of Business in Society, 5(1), 15-30. https://doi.org/10.1108/14720700510583430

Spanos, L. J., Tsipouri, L. J., \& Xanthakis, M. D. (2008). Corporate governance rating of family firms at the Athens Stock Exchange market. Managerial Finance, 34(7), 465-78. https://doi.org/10.1108/03074350810874424

Spathis, C. \& Georgakopoulou, E., (2007). The adoption of IFRS in South Eastern Europe: the case of Greece. International Journal of Financial Services Management, 2(1-2), 50-63. https://doi.org/10.1504/IJFSM.2007.011671

Stark, O., \& Falk, I., (1998). Transfers, empathy formation and reverse transfers. American Economic Review, 88(2), 271-6.

Tsangarakis, N. V. (2004). The price performance of Initial Public Offerings in Greece. Managerial Finance, 30(10), 26-44. https://doi.org/10.1108/03074350410769335

Tsipouri, L., \& Xanthakis, M., (2004). Can corporate governance be rated? Ideas based on the Greek experience. Corporate Governance: An International Review, 12(1), 16-28. https://doi.org/10.1108/03074350410769335

\section{Notes}

Note 1. As a measure of ownership concentration the authors define the average and median of ownership percentage of the three largest shareholders for the ten, non-financial, largest capitalization listed firms.

Note 2. Makridakis et al. (1997) argued that there is a dualism on Hellenic firms and that the Hellenic corporate model is more "paternalistic" compared to other developed countries; specifically, they found that "on the one extreme there are subsidiaries of multinational corporations operating in Greece, those firms which have established long-term strategic alliances with companies from abroad. At the other extreme there are family-owned businesses which are, more often, managed by their founder and major owner or his descendants..." (Makridakis et al., 1997, p. 385).

Note 3. See in addition: a) Stark and Falk, 1998; b) De Paola and Scoppa, 2001 and c) Berghe and Carhon, 2003.

Note 4. Family business is common to Continental Europe countries; what is unique in Hellas is that families tend to last only for one generation (Ballas, 1994, p. 120, note 1).

Note 5. Spanos et al. (2004, p. 3) state "confusing family and business matters, family owners could favor family interests over the firm's interests because of loyalty towards family. Family firms may encourage internal labor market schemes (within-family promotion), rather than competent recruitment processes".

Note 6. This kind of expropriation leads to sub-optimal levels of investments for minority shareholders; the agency conflict in these situations is not between strong management and weak owners-shareholders but between strong blockholders and weak minority owners (Fama and Jensen, 1983 and Jensen and Meckling, 1976).

Note 7. This reduction of listing companies is an international phenomenon and is called "listing gap". 
Note 8. Their sample included the ten stocks with higher market capitalization from the three ASE indices: a) FTSE ASE 20, FTSE ASE 40 and FTSE ASE 80 (Alexakis et al., 2006, p. 677, last paragraph).

Note 9. For a detailed review of the evolution of CG in Hellas see: a) Spanos (2005, p. 26) and b) Neratzidis and Filos (2014, p. 297).

Note 10. Hellas has followed the European Union (EU) directives 2006/46/EC and 2007/63/EC (Koutoupis, 2012; Neratzidis, 2015 and Neratzidis et al. (2015).

Note 11. This positive impact was basically from (fixed) assets valuation in fair price, while the negative impact was through the application of: i) IFRS 19 "employee benefits", ii) IFRS 26 "Accounting and reporting by retirement benefit plans and iii) the provision of bad debts.

Note 12. Ballas et al. 1998 (or Ballas 1994) stated first the expression "low-trust" society.

Note 13. Previous studies regarding Hellenic firms profitability examined: a) bank profitability (Athanasoglou et al., 2005 and Kosmidou et al., 2005) and b) manufacturing firms (Agiomirgianakis et al., 2006 and Papadogonas, 2005).

Note 14. Regarding size the authors used the Logarithm of permanent employees in the first year of the IPO.

Note 15. The same results were also in the studies of: a) Florou and Galarniotis (2007), b) Lazarides and Drimpetas (2011) and c) Neratzidis (2015).

Note 16. The body responsible for "auditing" auditors' work.

\section{Copyrights}

Copyright for this article is retained by the author(s), with first publication rights granted to the journal.

This is an open-access article distributed under the terms and conditions of the Creative Commons Attribution license (http://creativecommons.org/licenses/by/4.0/). 